\title{
Let that Be Your Last Battlefield: Tutankhamun and Disability
}

\author{
By Alexandra F. Morris*
}

\begin{abstract}
Tutankhamun is the most iconic and recognized figure from ancient Egypt but remains embroidered and hyperbolized. There has been little to no recognition or consensus within scholarly communities of his disability or how his disability may have factored into his personal, political, religious, and social roles within Egyptian society. Instead, he remains the perfect face of a pharaoh. There has been little consideration or research into whether his tomb was adapted to fit his needs as a disabled man. This article explores how Tutankhamun's tomb was perhaps modified to fit his needs as a disabled man, through an examination of the tomb layout, certain artifacts, botanical materials, artwork, and other grave goods. It also posits that disability need not be hyperbolized into an all or nothing proposition, and his injuries and death may have been caused by a confluence of events.
\end{abstract}

\section{Introduction}

Howard Carter's discovery of the tomb of Tutankhamun is one of the most renowned archaeological finds in history. Tutankhamun himself remains a strongly debated historical figure. Rather than ending the debate and ameliorating attitudes over Tutankhamun, current technology has only served to polarize and enflame reactions on all sides of the debate. ${ }^{1}$ However, this debate has taken on a life of its own, overshadowing even Tutankhamun himself. This has distorted his historical self to unimportant background information. To some, evidence now points to his having had several potentially disabling conditions. These disabilities are thought to include clubbed foot and Köhler disease, in addition to cleft palate, as found in medical scans completed by Dr. Albert Zink's team in late 2014..$^{2}$ There is also evidence of his disabilities in the tomb itself, first noticed independently before the scans were published. ${ }^{3}$ By bringing a new perspective to the tomb layout, certain artifacts, botanical materials, artwork, and other grave goods, it is possible by viewing this evidence holistically, to now consider the possibility that Tutankhamun's tomb may have been modified to fit his needs as a disabled person.

"Doctoral Candidate in History, Teesside University, United Kingdom.

1. Jo Marchant, The Shadow King: The Bizarre Afterlife of King Tut's Mummy (New York: Da Capo Press, 2013), 178-85.

2. Rossella Lorenzi, "King Tut Re-Creation Presents a Shocking Image," Discovery News (2014).

3. Alexandra F. Morris, "Let the Artifacts Speak: A Look at the Physically Disabled of Ancient Egypt" (MA diss., University of Pennsylvania, June 2014), 3-26, 60-77. 


\section{Evidence of Disability and Accommodations}

Tutankhamun's tomb contained many chairs and stools. While we do not have another tomb as well preserved with which to make a comparison, the number of chairs and stools found in the tomb should not be ignored if Tutankhamun's disabilities are considered. Some of the chairs could have been used as either litters or palanquins, whose use was well established by this time period. ${ }^{4}$ Tutankhamun's golden throne, nearly as recognizable as his funerary mask, shows signs of ancient repairs to the arms, something that might have been necessary had he been repeatedly gripping the arms to support himself as he stood. ${ }^{5}$ Additionally, several of his chairs and thrones, including the golden throne, originally were found with linen straps attached to their backs. ${ }^{6}$ No one is quite sure about their intended purpose. ${ }^{7}$ Current theories surrounding their use include them acting as a placeholder indicating that others not sit on the throne when the king was not present, or that they were used instead as a type of apparatus for transporting the empty throne. ${ }^{8}$ However, artistic depictions of Egyptians carrying thrones for transport, present in numerous tomb paintings, do not show the use of any straps. Instead the art depicts workers holding completely different sections of the thrones than where the straps were located. ${ }^{9}$ Additionally, it seems unlikely that a placeholder would have been necessary given the king's status. It seems plausible, given what we now know about Tutankhamun's disabilities that the straps may have acted as a means to secure him to his chairs and thrones, almost like a type of seatbelt or harness, especially if he had been carried around in them. Unfortunately, since these mysterious straps have only survived in photos, they cannot be examined for use and we may never know.

In total there were twelve stools, at least seven chairs, and eight additional footrests that were not associated with any chairs or stools. ${ }^{10}$ We know

4. Norman De Garis Davies, The Rock Tombs of el-Amarna, Parts III and IV (London: Egypt Exploration Society, 1903), 1-25; Cyril Aldred, Akhenaten: King of Egypt (London: Thames and Hudson, 1988), 279.

5. Marianne Eaton-Krauss, The Unknown Tutankhamun (New York: Bloomsbury, 2016), 23-25.

6. Eaton-Krauss, The Thrones, Chairs, Stools, and Footstools from the Tomb of Tutankhamun (Oxford: Griffith Institute, 2008), 26, 57.

7. Eaton-Krauss, The Thrones, Chairs, Stools, and Footstools, 26, 57.

8. Christian Loeben, "La Fonction Funeraire des Meubles Egyptiens" (The Funeral Function of Egyptian Furniture), Egypte, Afrique \& Orient 3 (1996): 25; Eaton-Krauss, The Thrones, Chairs, Stools, and Footstools, 26.

9. Loeben, "La Fonction Funeraire des Meubles Egyptiens," 25; Eaton-Krauss, 26.

10. Eaton-Krauss, 7-8. 
Tutankhamun's tomb is the best-preserved tomb discovered so far, and it is possible this number was not unusual. However, it is something that potentially opens further lines of inquiry. Similarly, all 145 pairs of Tutankhamun's underclothes were counted and cataloged..$^{11}$ That number is exceptionally high, however, as clothes were usually worn in sets and he only had 10 robes. This underwear could be suggestive of the king suffering from incontinence of some kind, and that would possibly point to the ancient Egyptians accounting for and providing for such a condition in the afterlife.

Another possible piece of evidence of his disability is that Tutankhamun was buried with over a hundred and thirty walking sticks, some of which appeared to have been used during his lifetime. One walking stick is even referenced, in a hieroglyph inscription, as having been his favorite. ${ }^{12}$ There have been other examples of disabled individuals being buried with tools they needed for mobility. In the early 1900s, the University of Pennsylvania Museum of Archaeology and Anthropology acquired an example of an older man from the 5th dynasty, originally found in Deshasheh, buried with a cane. He is now believed to have had polio, which resulted in one leg being shorter than the other. ${ }^{13}$ Polio seems to have been a fairly common disease in ancient Egypt, as seen in other individuals such as Roma the Doorkeeper from the New Kingdom, although some Egyptologists speculate that cerebral palsy could have been common as well. ${ }^{14}$ Disabled ancient Egyptians were probably not uncommon, as we have numerous artistic depictions of them in Egyptian art. ${ }^{15}$

Howard Carter cataloged all one hundred and thirty of these walking sticks. Carter himself mentioned, "The young Tutankhamun must have been an amateur collector of walking sticks and staves, for here, as in the Antechamber, and the burial chamber, we found a great number. They were of no doubt, in part of ritual significance, but many of them have evidently

11. Gillian Vogelsang-Eastwood, Tutankhamun's Wardrobe: Garments from the Tomb of Tutankhamun (Rotterdam: Barjestch van Waalwijk van Doorn and Co's, 1999), 19, 48-50; Brenda Fowler, "Forgotten Riches of King Tut: His Wardrobe," The New York Times, July 25, 1995.

12. Nicholas Reeves, The Complete Tutankhamun (London: Thames and Hudson, 1990), 178.

13. "Mummy Skeleton Man," UPenn Museum, last modified 2017, https://bit.ly/2 L26Qug.

14. Joyce Filer, Disease (Austin: University of Texas Press, 1995), 74; Aidan Dodson, ARCE Conference Feedback to Alexandra Morris, American Research Center in Egypt Conference, Kansas City, Missouri, April 21, 2017.

15. Morris, "Let the Artifacts Speak," 4-60; Heba Mahran and Samar Mostafa Kamal, "Physical Disability in Old Kingdom Tomb Scenes," Athens Journal of History 2, no. 3 (2016): 169-91. 
seen daily use."16 The evidence of daily use was not considered of primary importance. Some modern Egyptologists have hypothesized that walking sticks were seen as status symbols. ${ }^{17}$ However despite being the only pharaoh to have an intact tomb, it seems strange that no other pharaoh has been discovered with the large number of sticks that Tutankhamun had. Plus, as mentioned earlier and seen below, there have been commoners discovered with sticks that were clearly used as mobility aids. ${ }^{18}$ Yet it is interesting to note that William Flinders Petrie, teacher of Howard Carter, had discovered and published the Deshasheh mummy in 1898, over 20 years before Tutankhamun's discovery, and mentioned that the mummy's, "left thigh...was completely united in one mass, but two inches too short. A stick had therefore been carried to walk with, and this lay by the body."19 Carter had also documented another disabled person (the Queen of Punt) when he copied reliefs from Hatchepsut's mortuary temple several years prior. ${ }^{20}$ The anatomist, Douglas Derry, most likely would have recognized the malady during his initial examination of the King. A remedy for clubbed foot had been known and in use in Europe for over 70 years at the time of Tutankhamun's discovery. ${ }^{21}$

Another piece of evidence published by Egyptologist Andre Velmeijer in 2011, while completing a study on the footwear of ancient Egyptians, found that Tutankhamun's sandals had an extra horizontal strap located just above the toes that appeared on no other ancient Egyptian shoes. ${ }^{22}$ There were over eighty pairs of footwear found in Tutankhamun's tomb in addition to the hundred and thirty walking sticks. Velmeijer's theory is that these extra straps functioned as a kind of orthopedic shoe, which helped stabilize the foot and may have helped Tutankhamun to walk. ${ }^{23} \mathrm{He}$ also notes that most of Tutankhamun's sandals have a distinct wear pattern on the left foot, which is believed to be the clubbed foot. ${ }^{24}$ It is also interesting to note that footwear worn by Egyptian pharaohs typically

16. Howard Carter, The Tomb of Tut.ankh.amen Volume 3: The Annexe and Treasury. (London: Cassell \& Company Ltd., 1923), 94.

17. Toby A. H. Wilkinson, Early Dynastic Egypt (New York: Routledge, 1999), 158; Gay Robins, The Art of Ancient Egypt (Cambridge: Harvard University Press, 2008), 52; Thomas H. Maugh II, "CT Scan convince Egyptian researchers that King Tutankhamun wasn't murdered," Los Angeles Times, March 9, 2005.

18. W. M. Flinders Petrie, Deshasheh, 1897 (London: Egypt Exploration Fund, 1898), 18.

19. Petrie, Deshasheh, 1897, 18.

20. Paul Collins, Discovering Tutankhamun (Oxford: Ashmolean Museum, 2014), 20-1.

21. Matthew B. Dobbs et al., "Treatment of Idiopathic Clubfoot: A Historical Review," The Iowa Orthopedic Journal 20 (2000): 59-64.

22. Andre J. Velmeijer, Tutankhamun's Footwear: Studies of Ancient Egyptian Footwear (Leiden: Sidestone Press, 2011), 130-8.

23. Velmeijer, Tutankhamun's Footwear, 138-43.

24. Velmeijer, 208-21. 
featured iconography that allowed Egypt's enemies to be trampled underfoot. ${ }^{25}$ In Tutankhamun's case however, these enemies appeared on his canes and walking sticks instead allowing them to be crushed by hand instead of trodden underfoot.

Also found in the tomb were a rather large number of plants and herbs. While burial with food and other herbs was typical for an ancient Egyptian, the sheer number of these items in Tutankhamun's tomb is unusual. There are also botanical items found in Tutankhamun's tomb and his embalmer's tomb that have never been found anywhere else, out of all the currently excavated tombs of Egypt. $^{26}$ (See appendix for a more detailed look of the botanical remains.) However, by acknowledging Tutankhamun's disability, the presence of all these plants might begin to make sense. Out of at least 84 plants found within the tomb, 75 are known to have had medicinal uses in ancient Egypt. ${ }^{27}$ Out of these botanical remains, the majority are known to have been used as analgesics, as antiseptics and as antipyretics. ${ }^{28}$ These plants would have been a necessity for Tutankhamun in the afterlife considering the pain that a clubbed foot would have caused him. He was also suffering from a broken leg, now thought to have possibly contributed to his death, which would have caused even more excruciating pain. In addition to this, Tutankhamun is now thought to possibly have had malaria and Köhler disease, a bone disorder resulting in possible necrosis of the foot. All of these are known to cause discomfort and pain. ${ }^{29}$ The broken leg in addition to his other disabilities most likely made all these drugs/ medicinal plants medical necessities.

The placement of these items within the tomb is also significant as they are primarily clustered in three locations: by the life size guardian statues near the tomb entrance; by the stack of beds, chairs and stools; and in, next to, or on Tutankhamun's sarcophagi or actual mummy. ${ }^{30}$ This suggests that items in Tutankhamun's tomb were strategically placed to better accommodate him and manage his medical/physical needs. If as hypothesized, Tutankhamun had mobility issues, the placement of items cannot be ignored; placement is no longer random, but deliberate. In other words, everything he needed in the after life, was readily accessible to him with little movement required on his part. Careful thought seems to have been given to Tutankhamun's mobility and comfort in the afterlife. This also suggests that despite all his physical complications, the Egyptians had both the knowledge and motivation to keep

25. Wilkinson, Early Dynastic Egypt, 162.

26. Morris, "Let the Artifacts Speak," 60-77.

27. Morris, 60-77.

28. Morris, 60-77; Zahi Hawass et al., "Ancestry and Pathology in King Tutankhamun's Family," Journal of the American Medical Association 303, no. 7 (2010): 644-6.

29. Hawass et al., "Ancestry and Pathology in King Tutankhamun's Family," 644-6; Lorenzi, "King Tut Re-Creation Presents a Shocking Image."

30. Reeves, The Complete Tutankhamun, 211. 
him, as well as other disabled individuals, alive and comfortable. How do we know? There are numerous artistic depictions of other adult disabled individuals such as Roma the Doorkeeper, dwarves, and pyramid workers, as well as the mummified remains of these individuals, that come from a variety of social classes and time periods in ancient Egyptian history. ${ }^{31}$ This makes it possible to surmise that such compassion and careful planning was not limited to the royal family during the New Kingdom. ${ }^{32}$

The lotus flower, itself invites another line of inquiry. Lotuses had appeared before in Egyptian tombs, usually as hair ornamentations, or in garden scenes as seen in the tomb of Nebamun, also from the 18th dynasty. ${ }^{33}$ The lotus was also the symbol of upper Egypt. ${ }^{34}$ They were a popular motif in the later Ramesside Period (19th dynasty-20th dynasty), but were never found in the large quantities seen in Tutankhamun's tomb. ${ }^{35}$ When compared to the tomb of his immediate successors and advisors, the lotus motifs are conspicuously absent from Aye's, Horemheb's, and Maya's tombs, despite the same artistic style. ${ }^{36}$ In Tutankhamun's tomb the lotus can be found almost everywhere. ${ }^{37}$ In addition to actual botanical materials, the lotus was depicted numerous times artistically. It is on jewelry, furniture, in wall paintings, on other images of the king found within the tomb, and even on his shoes and clothing. ${ }^{38}$ There were so many lotuses found in the tomb both artistically and in actual botanical remains that according to Dr. Stephen Phillips, as well as F. Nigel Hepper, Tutankhamun's tomb had the most lotus flowers found in it of any tomb in all of ancient Egyptian history. ${ }^{39}$ The key point to keep in mind, is that research done by Rosso and Benson Harer, Jr. reveals the lotus flower was used medicinally in ancient Egypt as a pain reliever and sleep aid. It seems reasonable to conclude that the ancient Egyptians deliberately placed all these lotuses and lotus imagery

31. Morris, "Let the Artifacts Speak," 4-60; Mahran and Kamal, "Physical Disability in Old Kingdom Tomb Scenes," 169-91.

32. Morris, 4-60.

33. Jaromir Malek, Egypt: 4000 Years of Art (New York: Phaidon Press, 2003), 229.

34. David P. Silverman, Masterpieces of Tutankhamun (New York: Abbeville Press, 1978), 61, 79.

35. Dodson, Amarna Sunset: Nefertiti, Tutankhamun, Ay, Horemheb and the Egyptian Counter-Reformation (New York: American University in Cairo Press, 2009), 667.

36. Dodson, Amarna Sunset, 66-7; Geoffrey T. Martin, The Tomb of Maya and Meryt: The Reliefs, Inscriptions, and Commentary (London: Egypt Exploration Society, 2012), 64-9, plates $25,29,35,52,53$.

37. Dodson, 66-7; Martin, The Tomb of Maya and Meryt, 64-9, plates 25, 29, 35, 52, 53.

38. Morris, "Let the Artifacts Speak," 4-32.

39. Stephen Phillips, "Pharaoh's Flowers: Botanical Treasures from the Fabled Tomb of Tutankhamun," Public Lecture, Event from the Pennsylvania Museum of Archaeology and Anthropology, Philadelphia, May 19, 2013; F. Nigel Hepper, Pharaoh's Flowers: The Botanical Treasures of Tutankhamun (London: HMSO, 1990), 10-12, 16. 
within Tutankhamun's tomb to ensure that he was comfortable and well provided for in the afterlife. ${ }^{40}$

One of the current theories about Tutankhamun's death is that he fell out of or was hit in the chest by a moving chariot, breaking his leg. ${ }^{41}$ Coupled with a weakened immune system (possibly from malaria) the injury killed him. ${ }^{42}$ It should be noted that some of the artwork depicting Tutankhamun in a chariot portrays him as able-bodied, but this might be a continuation of traditional artistic motifs depicting the pharaoh that were typically used for propaganda purposes..$^{43}$ Injuries found on Tutankhamun's mummy may, in fact, be the result of repeatedly falling down or into things in his efforts to be independently mobile. Given Tutankhamun's disabilities it is highly unlikely that he could have ridden in a chariot. A far more likely explanation is that Tutankhamun simply fell and broke his leg, perhaps while on procession to various temples or at his rest house, sometimes referred to as a hunting lodge. ${ }^{44}$ Tutankhamun could easily have suffered the broken leg falling in the bath, falling out of bed, or falling from one of his chairs, thrones, or palanquins when he attempted to get up. If he fell from his palanquin, especially if it was currently in use, this would have meant a fall of at least two feet up to about four feet, since artistic depictions show the Egyptians carrying them at least at waist height. ${ }^{45}$ When one takes into account an earlier theory by Dr. Ashrafian, who states that Tutankhamun might have had temporal lobe epilepsy, the reason for these injuries and an explanation for the fall that ultimately resulted in his death becomes less certain than had previously been assumed. ${ }^{46}$ It should be noted that malaria can also cause seizures as well as brain damage in children. ${ }^{47}$ Tutankhamun could have had a seizure that resulted in a fall, perhaps while he was being carried in one of his canopied chairs, and acquired the broken leg that way. We simply do not

40. Ana Maria Rosso, "Poppy and Opium in Ancient Times: Remedy or Narcotic?" Biomedicine International 1 (2010): 83-4; W. Benson Harer Jr., "Pharmacological and Biological Properties of the Egyptian Lotus," Journal of the American Research Center in Egypt 22 (1985): 49-54.

41. Mary Beth Griggs, "New Theory: King Tut Died in a Chariot Crash," Smithsonian, November 4, 2013, https://bit.ly/2kqS6nB.

42. Griggs, "New Theory."

43. Malek, Egypt: 4000 Years of Art, 204; Silverman, Masterpieces of Tutankha-mun, 50 .

44. Hawass, The Golden King: The World of Tutankhamun (Washington DC: National Geographic, 2006), 55.

45. De Garis Davies, The Rock Tombs of el-Amarna, 1-25; Aldred, Akhenaten: King of Egypt, 279.

46. Hutan Ashrafian, "Familial epilepsy in the pharaohs of ancient Egypt's eighteenth dynasty," Epilepsy E Behavior 25 (2012): 29.

47. Richard Idro et al., "Cerebral Malaria: Mechanisms of Brain Injury and Strategies for Improved Neuro-Cognitive Outcome," Pediatric Research 68, no. 4 (2010): 267-74. 
know. To settle upon one explanation at the exclusion of others seems serendipitous. It is not only one possible answer, to the exclusion of others, but possibly a fatal confluence of events.

Another bit of evidence that hints at Tutankhamun's disability is the art depicted within his tomb on both the walls and other artifacts. In all the artistic depictions within Tutankhamun's tomb, he is shown either holding canes or walking sticks, sitting down, or literally being supported or held up by either the gods or his wife. ${ }^{48}$ Furthermore, all depictions seem to take great care in hiding or concealing his left foot, which we now know from scans to be his problem foot. ${ }^{49}$ This suggests that ancient Egyptian artisans were not only aware of his disability, but had acquired great skill, tact and protocols for rendering it so that the disability is acknowledged, but not to the point of distraction, detraction, or derision. Within the tomb there are also several depictions of lions - a well-established symbol of the pharaoh long before this point in Egyptian history. ${ }^{50}$ In order to help them stand upright, Tutankhamun's lions are leaning on supports, which also double as the Egyptian symbol for protection. When the depictions of Tutankhamun are compared to that of Pharaoh Akhenaten, his immediate predecessor, or that of either of Tutankhamun's successors, his general Horemheb, or advisor Aye, only Tutankhamun is depicted as physically supported by those around him or utilizing a stick of some type. ${ }^{51}$ This is important because according to current knowledge neither Akhenaten nor Horemheb, nor Aye, had any conditions that would have disabled them physically and limited their mobility. ${ }^{52}$ Tutankhamun is also shown being held up by others on monuments outside of his tomb as well. ${ }^{53}$ It further strengthens the idea that Egyptian society was accustomed to disabled people, as the artists appear to have already had an established protocol for depicting and tacitly acknowledging a disability without stigmatizing it. In the depiction of Seneb the dwarf from the Old Kingdom, his disability is depicted tactfully and in a humanizing way. ${ }^{54}$ In addition, we know that Seneb had custom designed furniture, including low stools, and a litter with a lower back designed to meet his adaptive needs. ${ }^{55}$ This same tact

48. Morris, "Let the Artifacts Speak," 4-32.

49. Hawass et al., "Ancestry and Pathology in King Tutankhamun's Family," 644-6; Reeves, The Complete Tutankhamun, 180; Katherine Stoddert Gilbert, Joan K. Holt, and Sara Hudson, ed., Treasures of Tutankhamun (New York: Bantam, 1976), 170-1.

50. Reeves, 180; Gilbert, Holt, and Hudson, Treasures of Tutankhamun, 170-1.

51. Morris, "Let the Artifacts Speak," 4-32.

52. Aldred, Akhenaten: King of Egypt, 51, 77, 236, 260; Hawass et al., "Ancestry and Pathology in King Tutankhamun's Family," 644-6.

53. Eaton-Krauss, The Unknown Tutankhamun, 56-8.

54. Veronique Dasen, Dwarfs in Ancient Egypt and Greece (Oxford: Oxford University Press, 1993), 130.

55. Dasen, Dwarfs in Ancient Egypt and Greece, 130. 
and humanization can be extended to a female helmsman with dwarfism found on a model boat in Tutankhamun's tomb. ${ }^{56}$ These, as well as numerous other artistic depictions of disabled Egyptians mentioned earlier, may show that ancient Egyptian society was accepting of those with other physical disabilities. ${ }^{57}$

Tutankhamun's tomb layout is suggestive of perhaps a hurried burial, but overall it shows careful forethought in planning for all of the king's needs in the afterlife. In the antechamber/first chamber of the tomb were most of Tutankhamun's stools, couches, and beds. In the doorway to the burial chamber, which is the next chamber over, were two life-sized statues both holding sticks. They were the same height as Tutankhamun and have been identified as "guardian figures." Most of the walking sticks were also located in this chamber. ${ }^{58}$ Since we already know that Tutankhamun had a clubbed foot and most likely required mobility assistance, perhaps these figures were also there to assist the king in his efforts to be mobile. Perhaps the king tried to be independently mobile, further evidenced when one goes past the burial chamber to the treasury, where there were more walking sticks. ${ }^{59}$ Another point to consider is that Tutankhamun's walking sticks were scattered throughout the tomb. Other items in large numbers, such as shoes and underwear, were found in collections in a single location.

The overall layout suggests that despite a seemingly haphazard appearance, the tomb was laid out so that the king would have assistance getting around no matter where he was within the tomb in his afterlife, and would have access to things that met all his needs as a disabled man. Considering the evidence, this explanation is at least plausible as traditional assumptions. For while the preparations may have been hurried, the Egyptians in fact did believe they were burying a god and his children. They were cognizant of the need for extra care.

The presence of the mummies of Tutankhamun's stillborn daughters, one of whom is believed to have had spina bifida, could also be seen as evidence of ancient Egypt's disability acceptance and of Tutankhamun's disabilities as well. ${ }^{60}$ Spina bifida has been shown to be related to clubbed foot and can be passed down genetically, which suggests the stillborn girl showing evidence of the condition inherited it from her parents, and provides yet another piece of evidence for Tutankhamun's own disabilities. ${ }^{61}$

56. Filer, Disease, 55-7.

57. Morris, "Let the Artifacts Speak," 4-60.

58. Reeves, The Complete Tutankhamun, 178-9.

59. Reeves, 178-9.

60. Reeves, Egyptian Medicine (Buckinghamshire: Shire Publications, 2001), 48.

61. Mayo Foundation for Medical Education and Research, "Diseases and Conditions: Clubfoot," Mayo Clinic, last modified 2014, https://mayocl.in/2lD6E3B. 
Stillborn babies and very young children were seldom mummified in ancient Egypt until the Ptolemaic Period. ${ }^{62}$ Yet these two babies were mummified, and were given their own sarcophagi, revealing a unique level of acceptance and compassion. It also proves that at the very least, these fetuses were recognized as human beings by their parents, by the priests who performed the mummification, and the artisans who crafted the tiny sarcophagi. One girl even had a small mask made for her; the other may have as well, but it was discovered in the embalmer's cache, which is somewhat strange.63 The inclusion of the girls in the tomb along with their disabled father, along with the dwarf figure, walking sticks and other accouterments, is evidence that, at the very least among the royal family, disability was accepted in ancient Egypt during this period. However, the numerous other depictions of disabled individuals throughout Egyptian history suggest that this acceptance may have extended to other levels of society and into other periods.

\section{Conclusion}

As Dr. Malek explained, Tutankhamun's discovery "doesn't belong to Egyptologists only. It doesn't even belong to Egypt only. The discovery belongs to everybody," including the disabled. ${ }^{64}$ It is interesting to note that even in current-day exhibitions and publications on Tutankhamun, his disabilities are still mostly ignored, and there is still debate as to whether he was disabled at all.65 Does making him able-bodied say more about our society today, than it does about the man himself? As Dr. Haj wrote in his book Disability in Antiquity, "Over the centuries millions of handicapped people have lived and died. They have been a substantial but voiceless minority." 66 We need to look at the ethos of the tomb in totality rather than as individual parts. By doing so, we can see a clearer picture of Tutankhamun as a disabled man and provide another way for all people see themselves validated in history. This will surely give Tutankhamun the respect he deserves both as a pharaoh and a disabled human being.

62. Reeves, Egyptian Medicine, 20.

63. Herbert Eustis Winlock, Tutankhamun's Funeral (New York: Metropolitan Museum of Art, 2010), 39-43; Joyce Tyldesley and Dorthea Arnold, Tutankhamen: The Search for an Egyptian King (New York: Basic Books, 2012), 52-3.

64. Marchant, The Shadow King, 80.

65. Traveling Museum Exhibition, The Discovery of King Tut, Premier Exhibitions, $5^{\text {th }}$ Avenue, New York; Hawass, Discovering Tutankhamun: From Howard Carter to DNA (New York: The American University in Cairo Press, 2013), 158-60.

66. Fareed Haj, Disability in Antiquity (New York: Philosophical Library, 1970), 11. 


\section{Appendix}

The chart below is a list of the fully identifiable plants and other botanical items found in Tutankhamun's tomb. Listed are their common names, scientific names, medicinal uses, and finally the sources in which each plant and medicinal use was verified can be found in corresponding footnotes, although Christian De Vartavan's Hidden Fields of Tutankhamun: From Identification to Interpretation of Newly Discovered Plant Material From the Pharaoh's Grave was the main source used. Plants marked with a * have only ever been found in Tutankhamun's tomb. Out of 84 identified botanical items, only 9 were unable to be identified as having some medicinal value, and 8 botanical items have never been found elsewhere in Egypt.

\section{Botanicals Found in Tutankhamun's Tomb}

\begin{tabular}{|l|l|l|}
\hline Plant & Scientific Name & Medicinal Uses \\
\hline Acacia (Nile acacia) $^{67}$ & $\begin{array}{l}\text { Acacia leguminosae, tortilis, } \\
\text { raddiana, nilotica, albida }\end{array}$ & laxative, demulcent \\
\hline Alisma*68 $^{* 6}$ & Aliscmaceae plantago & diuretic, astringent \\
\hline Almond Oil, Stones $^{69}$ & Prunus dulcis & laxative, diuretic \\
\hline $\begin{array}{l}\text { Balanos Oil, Egyptian } \\
\text { plum/ Heglig }^{70}\end{array}$ & Balanites aegyptiaca & unguent \\
\hline $\begin{array}{l}\text { Barley florets and } \\
\text { debris }\end{array}$ & Hordeum sativum & $\begin{array}{l}\text { to treat intestinal problems, } \\
\text { carminative }\end{array}$ \\
\hline Balm of Gilead $^{72}$ & Commiphora gileadensis & unguent \\
\hline Bedstraw $^{73}$ & Galium tricorne & diuretic, astringent \\
\hline Ben Oil ${ }^{74}$ & Moringa peregrina & anti-inflammatory, antiseptic \\
\hline
\end{tabular}

67. James P. Allen, The Art of Medicine in Ancient Egypt (New York: The Metropolitan Museum of Art, 2005), 102-3, 115; John Nunn, Ancient Egyptian Medicine (Norman: University of Oklahoma Press, 1996), 30-2, 72, 91, 152, 215.

68. Christian De Vartavan, Hidden Fields of Tutankhamun: From Identification to Interpretation of Newly Discovered Plant Material From the Pharaoh's Grave (London: Triade Exploration, 2002), 58; Walter H. Lewis and Memory P. F. Elvin-Lewis, Medical Botany: Plants Affecting Man's Health (New York: J. Wiley and Sons, 1977), 312.

69. Lise Manniche, An Ancient Egyptian Herbal (London: British Musem Press, 2006), 138-9; Irene Jacob and Walter Jacob, The Healing Past: Pharmaceuticals in the Biblical and Rabbanic World (Leiden: Brill, 1993), 42.

70. Manniche, An Ancient Egyptian Herbal, 81; Nunn, Ancient Egyptian Medicine, 140, 152, 160.

71. Nunn, 152; Jacob and Jacob, The Healing Past, 42-3.

72. Jacob and Jacob, 23.

73. Margaret Grieve, A Modern Herbal (New York: Dover, 1971), 462.

74. Nunn, Ancient Egyptian Medicine, 14, 152. 
Vol. 6, No. 1 Morris: Let That Be Your Last Battlefield: Tutankhamun and Disability

\begin{tabular}{|c|c|c|}
\hline Black Cumin ${ }^{75}$ & Nigella sativa & $\begin{array}{l}\text { poultice, laxative, disinfectant, anti- } \\
\text { inflammatory }\end{array}$ \\
\hline Blue Waterlily ${ }^{76}$ & Nymphaea cerulea & astringent, antiseptic, aphrodisiac \\
\hline Castor Oil ${ }^{77}$ & Ricinus communis & purgative, demulcent \\
\hline Wild Celery Leaves ${ }^{78}$ & Apium graveoleus & $\begin{array}{l}\text { diuretic, antirheumatic, } \\
\text { carminative, spasmolytic }\end{array}$ \\
\hline Chick-Peas $^{79}$ & Cicer arientinum & laxative \\
\hline Christthorn $^{80}$ & Ziziphus spina-christi & $\begin{array}{l}\text { laxative, febrifuge, purgative, } \\
\text { medical dressing for open wounds }\end{array}$ \\
\hline Cilician Fir ${ }^{81}$ & Abies cilcica & antiseptic, diuretic, carminative \\
\hline Cinquefoil ${ }^{* 82}$ & Pontentilla supina & anti-inflammatory \\
\hline Cocculus $^{83}$ & Cocculus hirsutus & diuretic \\
\hline Common Reed ${ }^{84}$ & Phragmites australis & antiseptic, poultice, anthelminthic \\
\hline Common Vetch $^{85}$ & Vica sativa & \\
\hline Coriander $^{86}$ & Coriandrum sativum & carminative, aromatic, narcotic \\
\hline Blue Cornflower87 & Centuarea depressa & $\begin{array}{l}\text { antipyretic, unguent, anti-venom } \\
\text { for scorpion stings }\end{array}$ \\
\hline $\begin{array}{l}\text { Date Palm Leaves and } \\
\text { Wine }^{88}\end{array}$ & Phoenix dactylifera & $\begin{array}{l}\text { astringent, antipyretic, antitussive, } \\
\text { poultice }\end{array}$ \\
\hline Darnel $^{89}$ & Lolium temulentum & sedative, anodyne \\
\hline Dock $^{90}$ & Rumex crispus & astringent, laxative \\
\hline
\end{tabular}

75. Manniche, An Ancient Egyptian Herbal, 81; Nunn, 152; Jacob and Jacob, The Healing Past, 40; Walter Wreszinski, Medizin der Alten Ä̈ypter: Band III: "Der Papyrus Ebers" (Medicine of the Ancient Egyptians: Volume III: "The Papyrus Ebers") (Leipzig, 1913), 28, 55, 125.

76. Nunn, 215.

77. Nunn, 33, 90, 140, 144, 152; Manniche, An Ancient Egyptian Herbal, 142-3.

78. Nunn, 154, 215.

79. Nunn, 14.

80. Nunn, 152, 216; Jacob and Jacob, The Healing Past, 34; Hepper, Pharaoh's Flowers, 68. 81. Hepper, 45.

82. Allen, The Art of Medicine in Ancient Egypt, 109, 115; Jacob and Jacob, The Healing Past, 117; De Vartavan, Hidden Fields of Tutankhamun, 58.

83. Hepper, Pharaoh's Flowers, 56.

84. Jacob and Jacob, The Healing Past, 43; Nunn, Ancient Egyptian Medicine, 63, 105.

85. De Vartavan, Hidden Fields of Tutankhamun, 43.

86. Wreszinski, Medizin der Alten Ägypter, 102-24; Nunn, Ancient Egyptian Medicine, 15, 152; Manniche, An Ancient Egyptian Herbal, 94.

87. Manniche, 85.

88. Nunn, Ancient Egyptian Medicine, 15, 94, 152, 215; Jacob and Jacob, The Healing Past, 41.

89. Jacob and Jacob, 42.

90. Jacob and Jacob, 72, 79. 


\begin{tabular}{|c|c|c|}
\hline Dodder ${ }^{91}$ & $\begin{array}{l}\text { Cuscuta pedicellata, } \\
\text { Cuscuta approximata }\end{array}$ & $\begin{array}{l}\text { analgesic, anthelminthic, anti- } \\
\text { inflammatory }\end{array}$ \\
\hline Echinaria ${ }^{* 92}$ & Echinara capitata & antiseptic \\
\hline Einkorn $^{93}$ & Trititcum monococcum & \\
\hline Emmer wheat ${ }^{94}$ & Trititcum dococcum & anti-inflammatory, anodyne \\
\hline Flax $^{95}$ & Linum usitatissimum & $\begin{array}{l}\text { purgative, anti-inflammatory, } \\
\text { antibacterial, laxative, antitussive, } \\
\text { anodyne, demulcent }\end{array}$ \\
\hline Frankincense $^{96}$ & Burseraceae boswellia & $\begin{array}{l}\text { anti-inflammatory, diuretic, } \\
\text { laxative, purgative, disinfectant }\end{array}$ \\
\hline Fenugreek $^{97}$ & $\begin{array}{l}\text { Trigonella foenum } \\
\text { graecum }\end{array}$ & $\begin{array}{l}\text { carminative, tonic, laxative, } \\
\text { expectorant, appetite stimulant }\end{array}$ \\
\hline Forrsk ${ }^{* 98}$ & Cornopus squamatus & anti-diarrheal, demulcent, diuretic \\
\hline Garlic $^{99}$ & Allium sativum & poultice, laxative, disinfectant \\
\hline Grape vine ${ }^{100}$ & Vitis vinifera & $\begin{array}{l}\text { diuretic, laxative, antitussive, } \\
\text { anodyne }\end{array}$ \\
\hline Grewia $^{101}$ & Grewia tenax & $\begin{array}{l}\text { anti-inflammatory, diuretic, } \\
\text { demulcent }\end{array}$ \\
\hline Halfa Grass ${ }^{102}$ & Desmotaachya bipinnata & \\
\hline Henna ${ }^{103}$ & Lawsonia inermis & astringent, sedative \\
\hline Honey ${ }^{104}$ & & poultice, antiseptic, unguent \\
\hline Rock Jasmine ${ }^{* 105}$ & Androsace maxima & anti-inflammatory \\
\hline Common Juniper 106 & Juniperus communis & diuretic, laxative \\
\hline Red Berried Juniper ${ }^{107}$ & Juniperus virginiana & diuretic, laxative \\
\hline
\end{tabular}

91. Grieve, A Modern Herbal, 810.

92. De Vartavan, Hidden Fields of Tutankhamun, 58.

93. De Vartavan, 46.

94. Manniche, An Ancient Egyptian Herbal, 152-153; Jacob and Jacob, The Healing Past, 42; Nunn, Ancient Egyptian Medicine, 152.

95. Nunn, 154, 215.

96. Francis L. Griffith, The Petrie Papyri: Hieratic Papyri from Kahun and Gurob (London: Quaritch, 1898), 12; Nunn, 94-5.

97. Nunn, 15, 154.

98. Grieve, A Modern Herbal, 642-3; De Vartavan, Hidden Fields of Tutankhamun, 58. 99. Jacob and Jacob, The Healing Past, 10, 36, 78; Nunn, Ancient Egyptian Medicine, 14.

100. Manniche, An Ancient Egyptian Herbal, 155-6; Jacob and Jacob, The Healing Past, 45.

101. Lewis, Medical Botany, 233.

102. Hepper, Pharaoh's Flowers, 33.

103. Hepper, 21, 25.

104. Nunn, Ancient Egyptian Medicine, 28, 32, 35, 63, 72, 90-1, 94-5, 105-6, 140, 143.

105. Grieve, A Modern Herbal, 447-9; De Vartavan, Hidden Fields of Tutankha-mun, 58.

106. Manniche, An Ancient Egyptian Herbal, 110-2; Hepper, Pharaoh's Flowers, 60; Nunn, Ancient Egyptian Medicine, 72, 152. 
Vol. 6, No. 1 Morris: Let That Be Your Last Battlefield: Tutankhamun and Disability

\begin{tabular}{|c|c|c|}
\hline Lentils ${ }^{108}$ & Lens culinaris & laxative \\
\hline Linseed Oil109 & Linum usitatissimum & $\begin{array}{l}\text { purgative, anti- inflammatory, anti- } \\
\text { bacterial, laxative, antitussive, } \\
\text { anodyne, demulcent }\end{array}$ \\
\hline Lotus Flowers ${ }^{110}$ & $\begin{array}{l}\text { Nymphaea lotus, } \\
\text { Nymphaea caerulea }\end{array}$ & aphrodisiac, antiseptic, astringent \\
\hline Lupin 111 & Lupinus & anthelmintic, diuretic, unguent \\
\hline Madder112 $^{112}$ & Rubia tinctorum & diuretic \\
\hline Madonna Lilies ${ }^{113}$ & Lilium candidum & $\begin{array}{l}\text { demulcent, anti-inflammatory, } \\
\text { unguent }\end{array}$ \\
\hline Mallow ${ }^{* 114}$ & $\begin{array}{l}\text { Malva neglecta, Malva } \\
\text { rotundifolia, malva parvi } \\
\text { flora }\end{array}$ & diuretic, poultice \\
\hline Mandrake Fruits ${ }^{115}$ & Mandragora officinarum & diuretic, purgative \\
\hline $\begin{array}{l}\text { Mayweed Leaves and } \\
\text { Flowers }^{116}\end{array}$ & Anthemis pseudocotula & poultice, carminative \\
\hline $\begin{array}{l}\text { Moringa/ } \\
\text { Horseradish Tree }{ }^{117} \\
\end{array}$ & Morring perengrina & diuretic, antiseptic \\
\hline Mustard Seed $^{118}$ & Brassica & poultice, laxative, anti- inflammatory \\
\hline Myrrh'119 & Commi phora myrrha & $\begin{array}{l}\text { anti- inflammatory, diuretic, } \\
\text { laxative, purgative, disinfectant }\end{array}$ \\
\hline Myrtle $^{120}$ & Myrtus communis & astringent, antiseptic \\
\hline Olive Leaves, Oil121 & Olea Europea & astringent, antiseptic, unguent \\
\hline Ox-Tongue Leaves ${ }^{122}$ & Picris radicata & anthelmintic \\
\hline
\end{tabular}

107. Hepper, 60; Nunn, 72, 152.

108. Manniche, An Ancient Egyptian Herbal, 115.

109. Nunn, Ancient Egyptian Medicine, 140, 152.

110. Manniche, An Ancient Egyptian Herbal, 126-9; Nunn, 14, 152, 157, 215; Harer Jr., "Pharmacological and Biological Properties of the Egyptian Lotus," 49-54; Rosso, "Poppy and Opium in Ancient Times, " 81-7.

111. Grieve, A Modern Herbal, 502-3.

112. Manniche, An Ancient Egyptian Herbal, 144.

113. Grieve, A Modern Herbal, 482.

114. Grieve, 507-9; De Vartavan, Hidden Fields of Tutankhamun, 58.

115. Jacob and Jacob, The Healing Past, 41; Nunn, Ancient Egyptian Medicine, 152, 154, 215.

116. Grieve, A Modern Herbal, 523-4

117. Nunn, Ancient Egyptian Medicine, 152.

118. Grieve, A Modern Herbal, 567-9.

119. Nunn, Ancient Egyptian Medicine, 94-5, 215; Allen, The Art of Medicine in Ancient Egypt, 109, 115.

120. Nunn, 152, 215; Jacob and Jacob, The Healing Past, 41.

121. Hepper, Pharaoh's Flowers, 16.

122. Grieve, A Modern Herbal, 605-6. 


\begin{tabular}{|c|c|c|}
\hline $\begin{array}{l}\text { Papyrus Pith, Stems, } \\
\text { Sedge }^{123}\end{array}$ & Cyperus papyrus & anti-inflammatory \\
\hline \begin{tabular}{|l|} 
Black Pea/ \\
Black Bitter Vetch \\
24
\end{tabular} & Lathyrus niger & \\
\hline Edible Pea Grass ${ }^{125}$ & Lathyrus sativus & \\
\hline Garden Pea ${ }^{126}$ & Pisum sativum, elatius & \\
\hline Rough Pea Vine ${ }^{127}$ & Lathyrus hirsutus & \\
\hline Panic Grass $^{128}$ & Panicum repens & \\
\hline $\begin{array}{l}\text { Paradoxical Canary } \\
\text { Grass }^{129}\end{array}$ & $\begin{array}{l}\text { Phalaris paradoxa, } \\
\text { Phalaris praemorsa }\end{array}$ & \\
\hline Persea Tree Leaves ${ }^{130}$ & Mimusops laurifolia & astringent, anthelmintic, antipyretic \\
\hline Pomegranate ${ }^{131}$ & Punica granatum & $\begin{array}{l}\text { anthelminthic, antibacterial, } \\
\text { antidiarrheal, astringent }\end{array}$ \\
\hline Poppy 132 & $\begin{array}{l}\text { Papaver rhoeas, Papaver } \\
\text { somniferum }\end{array}$ & narcotic, analgesic \\
\hline Prickle Grass ${ }^{133}$ & Crypsis & \\
\hline \begin{tabular}{|l|} 
Purple Galingale/ \\
Nut Grass $^{134}$ \\
\end{tabular} & Cyperus rotundus & $\begin{array}{l}\text { anti-inflammatory, antipyretic, anti- } \\
\text { malarial }\end{array}$ \\
\hline Safflower Oil, Seeds ${ }^{135}$ & Carthamus tinctorius & laxative, antipyretic \\
\hline Sedge $^{136}$ & Carex divisa & diuretic \\
\hline Sesame Oil, Seeds ${ }^{137}$ & Sesamum indicum & unguent, poultice, laxative, diuretic \\
\hline $\begin{array}{l}\text { Slender Meadow } \\
\text { Foxtail/Black } \\
\text { Twitch/Black Grass }{ }^{* 138}\end{array}$ & Alopecurus myosuroides & diuretic, demulcent \\
\hline
\end{tabular}

123. Nunn, Ancient Egyptian Medicine, 14, 72, 152; Jacob and Jacob, The Healing Past, 44. 124. Nunn, 152.

125. Nunn, 152.

126. Nunn, 152.

127. Nunn, 152.

128. De Vartavan, Hidden Fields of Tutankhamun, 46-7.

129. De Vartavan, 46-7.

130. Nunn, Ancient Egyptian Medicine, 152, 154, 215.

131. Nunn, $15,72,152$.

132. Manniche, An Ancient Egyptian Herbal, 130; Rosso, "Poppy and Opium in Ancient Times, " 81-7; Nunn, 151-2.

133. De Vartavan, Hidden Fields of Tutankhamun, 46.

134. Sri Ranajani Sivapalan, "Medicinal Uses and Pharmacological Activities of Cyperus rotundus Linn-A Review," International Journal of Scientific and Research Publications 3 (2013): 1-8.

135. Manniche, An Ancient Egyptian Herbal, 83; Nunn, Ancient Egyptian Medicine, 15.

136. Nunn, 14.

137. Manniche, An Ancient Egyptian Herbal, 147.

138. Grieve, A Modern Herbal, 370; De Vartavan, Hidden Fields of Tutankhamun, 58. 
Vol. 6, No. 1 Morris: Let That Be Your Last Battlefield: Tutankhamun and Disability

\begin{tabular}{|c|c|c|}
\hline Sorghum 139 & $\begin{array}{l}\text { Sorghum arundinaceum, } \\
\text { Sorghum bicolor }\end{array}$ & diuretic, demulcent \\
\hline Sycamore ${ }^{140}$ & Ficus sycomorus & poultice, antiseptic \\
\hline \begin{tabular}{|l|} 
Syrian Mesquite/ \\
Dwarf Mesquite $^{141}$
\end{tabular} & $\begin{array}{l}\text { Lagonychium } \\
\text { farctum/Prosopis farcta }\end{array}$ & diuretic, poultice, unguent \\
\hline Tamarisk ${ }^{142}$ & Tamarix & $\begin{array}{l}\text { anti-inflammatory, astringent, } \\
\text { anthelminthic, unguent }\end{array}$ \\
\hline Terebinth $^{143}$ & Pistacia palaestina & poultice, antiseptic, unguent \\
\hline Thyme* ${ }^{* 144}$ & Thymallus vulgaris & anthelminthic, laxative, carminative \\
\hline Watercress ${ }^{145}$ & Lepidium sativum & antipyretic \\
\hline Watermelon ${ }^{146}$ & Citrullus lanatus & $\begin{array}{l}\text { to treat blood vessel disorders, } \\
\text { laxative, carminative, anti- } \\
\text { inflammatory, unguent, poultice }\end{array}$ \\
\hline White Goosefoot ${ }^{147}$ & $\begin{array}{l}\text { Chenopodium album/ } \\
\text { iranicum }\end{array}$ & anti-inflammatory, anti-diarrheal \\
\hline Willow $^{148}$ & Salix subserrata & $\begin{array}{l}\text { analgesic, antipyretic, anti- } \\
\text { inflammatory, treatment of broken } \\
\text { limbs }\end{array}$ \\
\hline Wine ${ }^{149}$ & & $\begin{array}{l}\text { vessel for the administration of } \\
\text { medicinal substances }\end{array}$ \\
\hline Withania Nightshade ${ }^{150}$ & Withania somnifera & sedative, analgesic \\
\hline
\end{tabular}

139. Grieve, 130.

140. Manniche, An Ancient Egyptian Herbal, 103-5; Nunn, Ancient Egyptian Medicine, 15, 72, 85, 90, 131, 152, 154; Allen, The Art of Medicine in Ancient Egypt, 61, 98-9 102-3; Jacob and Jacob, The Healing Past, 36.

141. Jacob and Jacob, 48.

142. Manniche, An Ancient Egyptian Herbal, 149-50; Nunn, Ancient Egyptian Medicine, 152; Jacob and Jacob, 38.

143. Jacob and Jacob, 44,76 .

144. Jacob and Jacob, 44; Nunn, Ancient Egyptian Medicine, 15.

145. Grieve, A Modern Herbal, 845.

146. Jacob and Jacob, The Healing Past, 45; Nunn, Ancient Egyptian Medicine, 15, 152.

147. Grieve, A Modern Herbal, 857.

148. Jacob and Jacob, The Healing Past, 45; Nunn, Ancient Egyptian Medicine, 152.

149. Nunn, 72, 140; Allen, The Art of Medicine in Ancient Egypt, 68.

150. Nunn, 151; Hepper, Pharaoh's Flowers, 18. 


\section{Bibliography}

Aldred, Cyril. Akhenaten: King of Egypt. London: Thames and Hudson, 1988.

Allen, James P. The Art of Medicine in Ancient Egypt. New York: The Metropolitan Museum of Art, 2005.

Ashrafian, Hutan. "Familial epilepsy in the pharaohs of ancient Egypt's eighteenth dynasty." Epilepsy \& Behavior 25 (2012): 29.

Carter, Howard. The Tomb of Tut.ankh.amen Volume 3: The Annexe and Treasury. London: Cassell \& Company Ltd., 1923.

Collins, Paul. Discovering Tutankhamun. Oxford: Ashmolean Museum, 2014.

Dasen, Veronique. Dwarfs in Ancient Egypt and Greece. Oxford: Oxford University Press, 1993.

De Garis Davies, Norman. The Rock Tombs of el-Amarna, Parts III and IV. London: Egypt Exploration Society, 1903.

De Vartavan, Christian. Hidden Fields of Tutankhamun: From Identification to Interpretation of Newly Discovered Plant Material From the Pharaoh's Grave. London: Triade Exploration, 2002.

Dobbs, Matthew B., J. A. Morcuende, C. A. Gurnett, and I. V. Ponseti. "Treatment of Idiopathic Clubfoot: A Historical Review." The Iowa Orthopedic Journal 20 (2000): 59-64.

Dodson, Aidan. ARCE Conference Feedback to Alexandra Morris. American Research Center in Egypt Conference. Kansas City, Missouri, April 21, 2017. . Amarna Sunset: Nefertiti, Tutankhamun, Ay, Horemheb and the Egyptian Counter-Reformation. New York: American University in Cairo Press, 2009.

Eaton-Krauss, Marianne. The Unknown Tutankhamun. New York: Bloomsbury, 2016.

. The Thrones, Chairs, Stools, and Footstools from the Tomb of Tutankhamun. Oxford: Griffith Institute, 2008.

Filer, Joyce. Disease. Austin: University of Texas Press, 1995.

Fowler, Brenda. "Forgotten Riches of King Tut: His Wardrobe." The New York Times, July 25, 1995.

Gilbert, Katherine Stoddert, Joan K. Holt, and Sara Hudson, ed. Treasures of Tutankhamun. New York: Bantam, 1976.

Grieve, Margaret. A Modern Herbal. New York: Dover, 1971.

Griffith, Francis L. The Petrie Papyri: Hieratic Papyri from Kahun and Gurob. London: Quaritch, 1898.

Griggs, Mary Beth. "New Theory: King Tut Died in a Chariot Crash." Smithsonian. November 4, 2013, https://bit.ly/2kqS6nB.

Haj, Fareed. Disability in Antiquity. New York: Philosophical Library, 1970.

Harer Jr., W. Benson. "Pharmacological and Biological Properties of the Egyptian Lotus." Journal of the American Research Center in Egypt 22 (1985): 49-54. 
Hawass, Zahi, Yehia Z. Gad, Somaia Ismail, Rabab Khairat, Dina Fathalla, Naglaa Hasan, and Amal Ahmed. Discovering Tutankhamun: From Howard Carter to DNA. New York: The American University in Cairo Press, 2013. . "Ancestry and Pathology in King Tutankhamun's Family." Journal of the American Medical Association 303, no. 7 (2010): 644-6.

. The Golden King: The World of Tutankhamun. Washington DC: National Geographic, 2006.

Hepper, F. Nigel. Pharaoh's Flowers: The Botanical Treasures of Tutankhamun. London: HMSO, 1990.

Idro, Richard., K. Marsh, C. C. John, and C. R. Newton. "Cerebral Malaria: Mechanisms of Brain Injury and Strategies for Improved Neuro-Cognitive Outcome." Pediatric Research 68, no. 4 (2010): 267-74.

Jacob, Irene, and Walter Jacob. The Healing Past: Pharmaceuticals in the Biblical and Rabbanic World. Leiden: Brill, 1993.

Lewis, Walter H., and Memory P. F. Elvin-Lewis. Medical Botany: Plants Affecting Man's Health. New York: J. Wiley and Sons, 1977.

Loeben, Christian. "La Fonction Funeraire des Meubles Egyptiens" (The Funeral Function of Egyptian Furniture). Egypte, Afrique \& Orient 3 (1996): 25.

Lorenzi, Rossella. "King Tut Re-Creation Presents a Shocking Image." Discovery News, 2014.

Mahran, Heba, and Samar Mostafa Kamal. "Physical Disability in Old Kingdom Tomb Scenes." Athens Journal of History 2, no. 3 (2016): 169-91.

Malek, Jaromir. Egypt: 4000 Years of Art. New York: Phaidon Press, 2003.

Manniche, Lise. An Ancient Egyptian Herbal. London: British Musem Press, 2006.

Marchant, Jo. The Shadow King: The Bizarre Afterlife of King Tut's Mummy. New York: Da Capo Press, 2013.

Martin, Geoffrey T. The Tomb of Maya and Meryt: The Reliefs, Inscriptions, and Commentary. London: Egypt Exploration Society, 2012.

Maugh II, Thomas H. "CT Scan convince Egyptian researchers that King Tutankhamun wasn't murdered." Los Angeles Times. March 9, 2005.

Morris, Alexandra F. "Let the Artifacts Speak: A Look at the Physically Disabled of Ancient Egypt." MA diss., University of Pennsylvania, June 2014.

Nunn, John. Ancient Egyptian Medicine. Norman: University of Oklahoma Press, 1996.

Petrie, W. M. Flinders. Deshasheh, 1897. London: Egypt Exploration Fund, 1898.

Phillips, Stephen. "Pharaoh's Flowers: Botanical Treasures from the Fabled Tomb of Tutankhamun." Public Lecture, Event from the Pennsylvania Museum of Archaeology and Anthropology. Philadelphia, May 19, 2013.

Reeves, Nicholas. Egyptian Medicine. Buckinghamshire: Shire Publications, 2001. . The Complete Tutankhamun. London: Thames and Hudson, 1990.

Robins, Gay. The Art of Ancient Egypt. Cambridge: Harvard University Press, 2008. 
Rosso, Ana Maria. "Poppy and Opium in Ancient Times: Remedy or Narcotic?" Biomedicine International 1 (2010): 83-4.

Silverman, David P. Masterpieces of Tutankhamun. New York: Abbeville Press, 1978.

Sivapalan, Sri Ranajani. "Medicinal Uses and Pharmacological Activities of Cyperus rotundus Linn-A Review." International Journal of Scientific and Research Publications 3 (2013): 1-8.

Tyldesley, Joyce, and Dorthea Arnold. Tutankhamen: The Search for an Egyptian King. New York: Basic Books, 2012.

Velmeijer, Andre J. Tutankhamun's Footwear: Studies of Ancient Egyptian Footwear. Leiden: Sidestone Press, 2011.

Vogelsang-Eastwood, Gillian. Tutankhamun's Wardrobe: Garments from the Tomb of Tutankhamun. Rotterdam: Barjestch van Waalwijk van Doorn and Co's, 1999.

Wilkinson, Toby A. H. Early Dynastic Egypt. New York: Routledge, 1999.

Winlock, Herbert Eustis. Tutankhamun's Funeral. New York: Metropolitan Museum of Art, 2010.

Wreszinski, Walter. Medizin der Alten Agypter: Band III: "Der Papyrus Ebers" (Medicine of the Ancient Egyptians: Volume III: "The Papyrus Ebers"). Leipzig, 1913. 
